\title{
„DUCH RYCERSKI” CZY PRZECIĘTNOŚĆ? ZNAMIEROWSKI I TOCQUEVILLE - DWA PODEJŚCIA DO ELITY DEMOKRACJI
}

\begin{abstract}
Z agadnienie elit politycznych, choć dostrzeżone znacznie wcześniej, zostało rozwinięte w naukach społecznych na początku XX wieku. Termin elita wywodzi się od łacińskiego słowa eligo, co znaczy wybierać. Został on wprowadzony do nauk społecznych przez Vilfredo Pareto, ale dziś pojęcie „elita” jest wieloznacznie rozumiane i opisywane. Oprócz określenia „elita” i „elity” równolegle funkcjonują inne: elita władzy, elita rządząca, klasa rządząca, klasa polityczna, klasa panująca, przywództwo, grupa kontrolująca ${ }^{1}$. Powoduje to zamieszanie polegające na tym, iż tym samym pojęciom nadaje się różne etykiety i odwrotnie: te same etykiety stosuje się do pojęć odmiennych.

Niejasności pojawiaja się również w kwestii metody wyodrębniania elit politycznych. Różni badacze stosują odmienne kryteria. Zasadniczo pojawiaja się trzy główne tendencje w określaniu metod kwalifikowania jednostek do elity: metoda pozycyjna (elitę tworza osoby zajmujące strategiczną pozycję w państwie), metoda reputacyjna (elitę tworza osoby, które w mniemaniu opinii publicznej mają istotny wpływ na decyzje państwowe), metoda decyzyjna (elitę tworzą osoby rzeczywiście podejmujące decyzje lub mające na nie istotny wpływ $)^{2}$.

Również teorie elit politycznych dostarczaja bogactwa różnych interpretacji tego zagadnienia. Powstało wiele teorii elit i przedstawiając
\end{abstract}

\footnotetext{
${ }^{1}$ B. Dobek-Ostrowska, Elity polityczne, w: Studia z teorii polityki, pod red. A. Jabłońskiego, L. Sobkowiak, t. 2, Wydawnictwo Uniwersytetu Wrocławskiego, Wrocław 1998, s. 133.

2 J. Jartyś, M. Kempisty, R. Podgórzańska, L. Tomczak, Elita polityczna - aspekty teoretyczne, w: Wybrane problemy teorii polityki, Szczecin 2002, s. 45.
} 
je zasadniczo stosuje się podział na: teorie klasyczne (Mosca) i współczesne (Mills) lub ujęcie stratyfikacyjne (Pareto) i instytucjonalne (Weber). Jednak ja przedstawię teorie myślicieli zajmujących się tematyką elit w nieco inny sposób - za pomocą klasyfikacji stworzonej na potrzeby tego referatu. Głównym kryterium branym przeze mnie pod uwage będzie czynnik wartościujący tzn. to, w jaki sposób dany myśliciel oceniał, głównie pod względem funkcjonalności dla społeczeństwa i moralności, grupę będącą elita. W tak zbudowanej skali koncepcje Czesława Znamierowskiego i Alexisa de Tocqueville - myślicieli, których podejścia interesują mnie najbardziej - znajdą się na przeciwległych biegunach, co moim zdaniem, umożliwi jeszcze dobitniejsze podkreślenie różnic w ocenie elity władzy przez obu tych badaczy.

Czesław Znamierowski w swojej pracy Elita $i$ demokracja przedstawia warunki, jakim musi sprostać społeczeństwo, a przede wszystkim elita, na drodze do demokracji. Wychodzi on z założenia będącego krytyka naczelnej zasady demokracji, mówiącej, iż ludzie są sobie równi i dochodzi do wniosku, iż kluczem do zbudowania najlepszego ustroju jest to, ażeby „oligarchia, którą de facto jest każda demokracja, stała się arystokracją (ustrojem, w którym rządzą najlepsi)"”. Dlatego tak ważna z punktu widzenia istnienia demokracji jest elita $\mathrm{i}$ to, jakimi cechami odznaczaja się jej członkowie.

Dla Znamierowskiego „elita to zbiór ludzi wybrany w pewien określony sposób, zbiór ten posiada cechę wartościową dla zbiorowości, która go wybrała"4. W różnych okresach historycznych różne cechy moga być społecznie pożądane, dlatego istnieje wiele elit politycznych. Znamierowski wprowadza podział elit politycznych ze względu na określone cechy jej członków, ale za główną wadę tej klasyfikacji uważam to, iż jest ona skomplikowana, w pewnych miejscach nieczytelna, a przede wszystkim jest to podział nierozłączny tzn. niekiedy kategorie nakładają się na siebie. Znamierowski wyróżnił między innymi „elitę walorów” - należą do niej osoby wyróżniające się „wysokimi wartościami moralnymi”, „elitę funkcji” - grupę ludzi zajmujących wysokie stanowiska i pełniących odpowiedzialne funkcje będących fachowcami o „wysokich wartościach moralnych”. Jeżeli działanie tej elity jest korzystne dla społeczeństwa, to wtedy powstaje „elita zasługi”. Gromadzi ona w swoich szeregach osoby, które szczególnie przysłużyły się rozwojowi społeczeństwa i demokracji. Istnieje również „elita

\footnotetext{
${ }^{3}$ Cz. Znamierowski, Elita i demokracja, Warszawa 1991, s. 42.

${ }^{4} \mathrm{~K}$. Szafer, Znamierowski $i$ Tocqueville - dwa podejścia do elity w demokracji, „Colloquia Commun", 2002, nr 2, s. 438.
} 
godności”, czyli zbiór osób, które społeczność uznała za wybitne oraz „elita rycerska”, której członków charakteryzuje „postawa rycerska”. Postawa ta przejawia się w przeciwstawianiu się wszelkiemu złu, jakie spotyka społeczeństwo, dbaniu o potrzeby społeczeństwa, a nie elity. Elita rycerska prowadzi masy, ale też domaga się kontroli władzy elit. W obrębie elity nieunikniony jest „konflikt między pierwiastkiem pasożytniczym i rycerskim, ale element rycerski jest przeważający, gdyż najważniejszym kryterium przynależności do elity politycznej są walory moralne" . Jest to niezwykle idealistyczny obraz grupy stanowiącej elitę polityczną.

Nieco mniej optymistyczny obraz elity politycznej przedstawia inny klasyk tej problematyki: Vilfredo Pareto. Postrzega on elitę danego społeczeństwa jako ludzi o wysokim stopniu inteligencji i sprytu, ale wyklucza ocenę zasług i użyteczności tych klas dla społeczeństwa. Elita to grupa ludzi o „najwyższych zdolnościach w danej dziedzinie aktywności”’, kryterium staje się sukces i uchylona zostaje ocena moralna tej grupy. Pareto wskazuje również na nieuchronność procesu degeneracji elit politycznych, czemu daje wyraz w swojej „teorii krążenia elit".

Inny teoretyk, tak jak Pareto związany z włoską teoria polityki, Gaetano Mosca postrzega elitę polityczną w jeszcze „ciemniejszych barwach". Wskazuje, że elita bardzo często zdobywa posłuch poprzez atrybut siły. Legitymacja władzy jest dla elity określona formuła polityczna, lecz to nie formuła polityczna określa sposób tworzenia klasy politycznej, ale klasa polityczna wybiera sobie odpowiadająca jej w danym momencie formułę polityczna.

Kolejna koncepcja to koncepcja C. Wrigta Millsa przedstawiona w pracy Elita władsy, w której „elita to grupa ludzi zajmujących pozycje pozwalające im na podejmowanie decyzji mających znaczace konsekwencje" ${ }^{\prime 7}$. Mills, jako jeden z pierwszych badaczy, analize pojęciową poparł badaniami empirycznymi (przebadał życiorysy pięciuset trzynastu amerykańskich polityków). Z badań tych wyłania się mało optymistyczny obraz, według którego o postaci elity i działaniach przez nią podejmowanych „decyduje zbieżność interesów osób kontrolujących główne środki produkcji i przemocy" ".

Według Harolda Lasswella, następnego klasyka, elita to nic więcej niż tylko grupa ludzi posiadająca w jakiejś zbiorowości największą władzę.

${ }^{5}$ Cz. Znamierowski, dz. cyt., s. 42.

${ }^{6}$ J. Jartyś, M. Kempisty, R. Podgórzańska, Ł. Tomczak, dz. cyt., s. 45.

${ }^{7}$ B. Dobek - Ostrowska, dz. cyt, s. 136.

${ }^{8}$ C. Mills, Elity władzy, w: tenże, Elity władzy, Warszawa 1961, s. 373. 
Dla skompletowania składu elity nie sa istotne cechy jakościowe tej grupy: umiejętności, zdolności, wiedza, talent. Podstawowym kryterium wyodrębniania elity jest jej dostęp do różnorakich dóbr. Wobec czego, zdaniem Lasswela, „za elitę należy uznać tych, którzy otrzymuja najwięcej tego, co jest do otrzymania",

Również Alexis de Tocqueville nie miał najlepszego zdania o ludziach uprawiających politykę. W swojej pracy $O$ demokracji w Ameryce nie posługiwał się terminem „elita polityczna”, ale opisywał grupę będąca ówczesną elitą władzy. Określał ja w następujący sposób: „w labirynty polityki angażują się ludzie o umiarkowanych talentach osobistych. Wielkie talenty i wielkie umiejętności, zajęte zdobywaniem bogactwa, uchylają się w zasadzie od władzy; często się zdarza, że ktoś decyduje się poświęcić sprawom państwowym tylko dlatego, że nie jest zdolny do prowadzenia własnych interesów" ${ }^{\text {"10 }}$ Zdaniem Tocqueville’a w demokracji władzy nie sprawuja najbardziej wartościowi członkowie danego społeczeństwa; jedynym, co odróżnia tę grupę od mas, jest mandat wyborczy i poparcie większości, które otrzymali - to jedyne kryteria kwalifikujące do elity władzy. Tocqueville uważał, że wybitne jednostki stronią od polityki i pełnienia funkcji publicznych, stojąc tym samym poza elita polityczna.

Wiele $\mathrm{z}$ przedstawionych w powyższych teoriach zjawisk związanych $\mathrm{z}$ problematyką elit politycznych jest widocznych również w życiu współczesnej elity politycznej naszego kraju. Większość z nas jednoznacznie źle ocenia działalność elit i w kontekście przedstawionej przeze mnie skali zdecydowanie bliższa jest wizji Tocqueville’a niż Znamierowskiego. Nie ma oczywiście wątpliwości, co do tego, iż społeczeństwo ma pełne prawo do wyrażania tak negatywnych sądów, skłaniaja je do tego wydarzenia na naszej scenie politycznej. Wątpliwości mogą pojawić się w momencie zapytania o przyczyny takiego stanu rzeczy. Czy tutaj również będziemy bliżsi koncepcji Tocqueville’a mówiącej o tym, że jednostki wybitne stronią od polityki i tym faktem wytłumaczymy kształt obecnych elit politycznych w naszym kraju? Odpowiedzia może być też koncepcja Znamierowskiego, w której badacz twierdzi, iż elity to osoby posiadające cechy postrzegane przez społeczeństwo za najbardziej wartościowe. W tym kontekście kondycjanaszych elit politycznych to odbicie kondycji polskiego społeczeństwa. Która odpowiedź jest bliższa prawdy? Ocenę pozostawiam czytelnikowi.

${ }^{9}$ J. Jartyś, M. Kempisty, R. Podgórzańska, L. Tomczak, dz.cyt., s. 48.

${ }^{10}$ K. Szafer, dz. cyt., s. 441. 